\section{Current and Future Applications of Phytases in Poultry Industry:}

\section{A Critical Review}

\begin{abstract}
Phytases are enzymes that initiate the removal of phosphate from phytate. This enzyme has been widely utilized in animal feeding especially in the poultry industry to enhance phosphorus intake and minimize environmental pollution. Phytases are widely distributed in microbial, plants and animals. Supplementations of phytase into the diets of poultry have great impact to the improvement of poultry immune systems and increase bird weight. In addition to that, phytase are able to improve both quantity and quality of eggs, egg mass and eggshell quality. This review covers the classifications and distribution of phytases in different biofactors. In addition, it shed more light on the recent trends of application and beneficial impact in poultry farming.

Key Words: Phytase, Food and Feed supplements, Poultry feed, Functional Feed, Enzyme Supplement
\end{abstract}

\section{Introduction}

Animal feed, similar with the humans, is comprised of protein, carbohydrates, and fats. Protein typically comes from soybeans, carbohydrates from corn, and fats from vegetable oils or animal fat. However, animal feed contains many ingredients such as phytate phosphorous and non-starch polysaccharides that are poorly digested by livestock. Therefore, enzymes in animal feed are typically added with the intent to increase nutrient bioavailability by acting on feed components prior to or after consumption, and by maximizing the performance of nutrients in feed. Also, these enzymes help to remove anti-nutrients, increase the digestibility of nutrients and fiber, and supplement the enzymes that animals already produce. Therefore, nowadays, different enzymes of microbial origins such as amylases, xylanases, $\beta$-glucanases, proteases, phytases and many others are added to feed (Beshay et al., 2003; Beshay et al., 2011; El Enshasy et al., 2013, El Enshasy et al., 2016a; El Enshasy et al., 2016b; Elsayed et al., 2016; Kandiyil et al., 2018). Hence, it is of general importance that the enzymes are not inactivated prior to ingestion and they function under the conditions of the gastrointestinal (GI) tract (Pariza and Cook, 2010). Recently, animal feeds are formulated with enzymes as close as possible to a target animal's nutritional requirements to avoid excesses. Nevertheless, some enzymatic predigestion of the feed substrate may also occur during storage depending on the exposure time prior to ingestion of the feed by the animal.

Furthermore, animal feed is known to be the largest cost item in livestock and poultry production, accounting for $60-70 \%$ of total expenses. Animal feed and nutrient utilisation are influenced by numerous factors, a major one being the wide variety of compounds present in the feed ingredients (Figure 1).

\section{Review}

Daniel Joe Dailin ${ }^{a, b}$

Nor Hasmaliana Abd Manas ${ }^{b}$ Nur Izyan Wan Azlee ${ }^{b}$ Jennifer Eyahmalay ${ }^{a, b, c}$ Sarah Afiqah Yahaya ${ }^{d}$ Roslinda Abd Malek ${ }^{a}$

Vickpasubathysiwa Siwapiragam ${ }^{c}$

Dalia Sukmawati $^{\mathrm{e}}$

Hesham El Enshasy ${ }^{a, b, f_{*}}$

${ }^{a}$ Institute of Bioproduct Development (IBD),

Universiti Teknologi Malaysia (UTM), 81130 UTM, Skudai, Malaysia

${ }^{b}$ Department of Bioprocess and Polymer Engineering, School of Chemical and Energy

Engineering, Faculty of Engineering,

Universiti Teknologi Malaysia, 81310, Skudai, Johor, Malaysia

'SBG Agrifeed (M) Sdn Bhd, PLO 369, Jalan Emas 2, 81700, Pasir Gudang, Johor, Malaysia

${ }^{\mathrm{d}}$ Pusat Pengajian Biologi, Fakulti Sains Gunaan, Universiti Teknologi MARA, Kampus Kuala Pilah, Pekan Parit Tinggi, 72000 Kuala Pilah, Negeri Sembilan, Malaysia

${ }^{\mathrm{e}}$ Faculty of Mathematics and Natural Sciences, Universitas Negeri Jakarta, Jakarta, Indonesia

${ }^{\mathrm{f}}$ Biopocess Development Department, City for Scientific Research, New Burg Al Arab Alexandria, Egypt

Corresponding Author

Hesham El Enshasy

hesham@utm.my

Article info

Received: 29-08-2018

Accepted: 12-11-2018

DOI: 10.31797/vetbio.455687

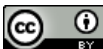

This work is licensed under a Creative Commons Attribution 4.0 International License 
Some of these tend to reduce diet quality, the feed efficiency and the growth rates of animals. The factors that influence the composition and utilization of the diets will thus have a substantial effect on the cost of poultry and other animal production (Acamovic, 2001). Producers of poultry and other animals always aim to provide high-quality products within a short span of time as possible at minimal cost. To save on costs, producers need to get smarter about optimizing animal production in a sustainable manner. The rapid growth achieved by monogastric animals generally necessitates that they are fed on high-quality diets with readily available nutrients. Enzymes offer an opportunity to do the job which enable them to produce more meat per animal or to produce the same amount of meat cheaper and faster. Throughout this short growing period, maintenance of a high health is really important to yield a good quality product. During the growth of poultry there is also an increasing demand to minimize the amount of waste material requiring disposal and this has implications for pollution of the environment.

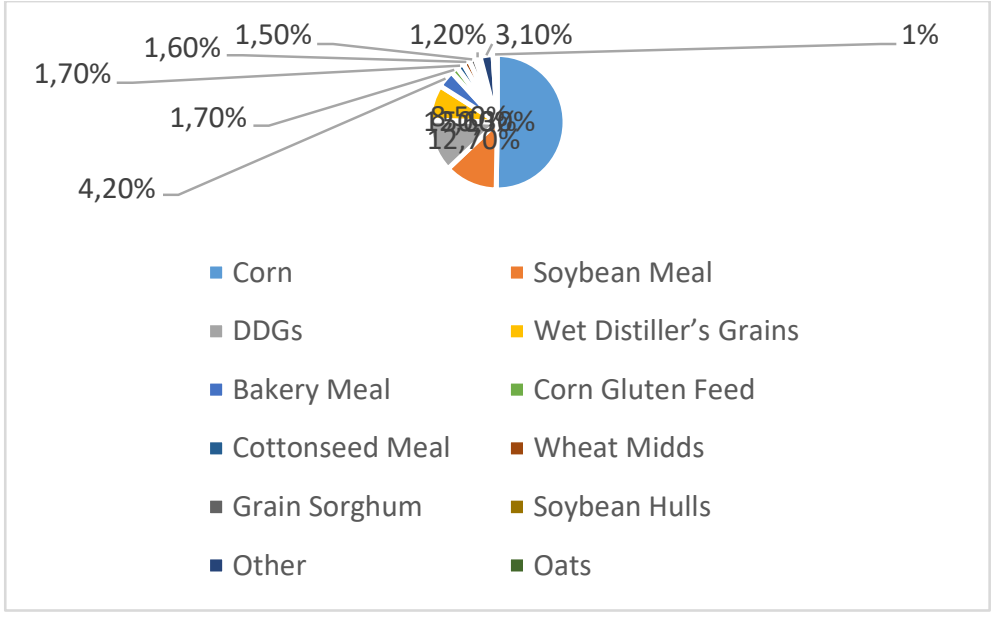

Figure 1. Total diet composition for top livestock and poultry in 2016

(Adapted from American Feed Industry Association, 2018)

\section{Enzymes in Animal Feed}

Found in all living cells, enzymes catalyse chemical processes that convert nutrients into energy and new tissue. They do this by binding to substrates in the feed and breaking them down into smaller compounds. Enzymes' mode of actions are very specific towards their preferred substrates and eventually converting them into specific products. Each enzyme offers different characteristics that affect their dietary inclusion rate where they work within the animal's gut and their overall efficacy. Enzyme supplements are used widely in animal diets in an attempt to improve nutrient utilisation, the health and welfare, product quality and to reduce pollution as well as to increase the choice and content of ingredients. Commercially- available enzymes can be derived from plants and animals as well as microorganisms. Considerable advances have been made during the last decade in the manufacture, activity, quality, thermostability and specificity of supplemental enzymes for use in animal diets (Acamovic 2001). There are various kind of enzymes currently used in the animal feed such as protease, which break down proteins into amino acids, carbohydrates, split carbohydrates into simple sugars, and lipases take apart lipids into fatty acids and glycerol. One of the most interesting and important factors of enzyme function is that each type has a very specific role within the animal.

Supplementation of diets for monogastric animals with enzymes has been progressively investigated and 
applied as a means of enhancing production efficiency and increasing the effectiveness of nutrient utilization. Supplementation of poultry diets with enzymes frequently exerts beneficial effects rather than the bad effects. It is well documented that supplementation of diets with exogenous enzymes can reduce the adverse effects of some compounds, especially those produced by carbohydrates and proteins (Bedford and Schulze, 1998). Enzyme supplementation has also been shown to influence the absorption of fats and fatty acids as well as fat-soluble microconstituents contained in the animal diets (Danicke et al., 1999). The extent of the benefit depends on a number of factors, such as the nature of the dietary components, whether or not the diets have been processed and whether the appropriate enzymes have been included for the substrates contained in the diets (Acamovic, 2001).

Enzymes are also provided in various forms for supplementation of animal diets. They can be supplied as powders and added to the diet before mixing and pelleting, or they can be added as granules before the diets are mixed and pelleted. Both these procedures allow the enzymes to mix intimately with the dietary ingredients and this allows them, at least potentially, to react effectively with their substrates (Acamovic, 2001). Many enzymes, however, tend to be thermolabile, and thus processing at high temperatures may reduce their activity (Silversides and Bedford,
1999). The method which involves the greatest technological input has been applied to synthesize these enzymes for animal feed especially for phytases production. This review will discuss and focus on phytases that are typically considered for use in animal feeds.

\section{Classification and distribution of phytases}

Phytases are enzymes categorized in the class of phosphatases (EC 3.1.3). These enzymes catalyze hydrolysis reaction to release inorganic phosphorus from phytate (Greiner, 2007). Phytases are widely distributed in plants, microorganisms, and animal (Humer et al., 2014). Phytases are internationally classified based on the enzymes stereospecificity of hydrolysis (Selle and Ravindran, 2007). Phytases that initiate hydrolysis of C3-position of phytic acid are classified as 3-phytases (EC 3.1.3.8). These hydrolysis reactions produce inorganic phosphate $(\mathrm{Pi})$ and 1,2,4,5,6-pentakisphosphate. On the other hand, phytases that initiate hydrolysis of C6-position of phytic acid are classified as 6-phytases (EC 3.1.3.26), and this reaction produces $\mathrm{Pi}$ and 1,2,3,4,5pentakisphosphate. Most phytases from microorganisms and filamentous fungi are 3-phytases, while plant phytases are 6-phytases (Reddy et al.,1982). Table 1 shows the production of phytases by different recombinant microorganisms.

Table 1. Production of phytases by recombinant microorganisms

\begin{tabular}{|c|c|c|c|c|}
\hline Microorganism & Source of phy gene & $\begin{array}{l}\text { Production } \\
\text { process }\end{array}$ & $\begin{array}{l}\text { Maximal } \\
\text { yield }\end{array}$ & Reference \\
\hline Lactococcus lactis & Escherichia coli & $\mathrm{SmF}$ & $19 \mathrm{U} \mathrm{mL}^{-1}$ & Pakbaten et al., 2018 \\
\hline Escherichia coli & $\begin{array}{l}\text { Theromotoga } \\
\text { naphthophila }\end{array}$ & $\mathrm{SmF}$ & $1000 \mathrm{IU} \mathrm{kg}^{-1}$ & Sabir et al., 2017 \\
\hline Pichia pastoris & Shigella sp. & $\mathrm{SmF}$ & $967 \mathrm{U} \mathrm{mg}^{-1}$ & Roy et al., 2016 \\
\hline Escherichia coli & Shigella sp. & $\mathrm{SmF}$ & $2982 \mathrm{U} \mathrm{mg}^{-1}$ & Roy et al., 2016 \\
\hline $\begin{array}{c}\text { Ogataea } \\
\text { thermomethanolica }\end{array}$ & Aspergillus niger BCC18081 & $\mathrm{SmF}$ & $134 \mathrm{U} \mathrm{mL}^{-1}$ & Charoenrat et al., 2016 \\
\hline Escherichia coli & Yersinia intermedia & $\mathrm{SmF}$ & $3849 \mathrm{U} \mathrm{mg}^{-1}$ & Mirzaei et al., 2016 \\
\hline Escherichia coli & Selenomonas ruminantium & $\mathrm{SmF}$ & $1204 \mathrm{U} \mathrm{mL}^{-1}$ & Lan et al., 2014 \\
\hline Pichia pastoris & Escherichia coli & $\mathrm{SmF}$ & $112 \mathrm{U} \mathrm{mL}^{-1}$ & Tai et al., 2013 \\
\hline $\begin{array}{c}\text { Escherichia coli } \\
\text { DH5a }\end{array}$ & $\begin{array}{c}\text { Etrobacter } \\
\text { sakazakii ASUIA279 }\end{array}$ & SSF & $4194 \mathrm{U} \mathrm{mL}^{-1}$ & Ariff et al., 2013 \\
\hline $\begin{array}{c}\text { Ogataea } \\
\text { thermomethanolica }\end{array}$ & $\begin{array}{l}\text { Aspergillus thermostable } \\
\text { phytase }\end{array}$ & SSF & $134 \mathrm{U} \mathrm{mL}^{-1}$ & Charoenrat et al., 2016 \\
\hline
\end{tabular}

SmF; Submerged Fermentation, SSF: Solid State Fermentation. 
Phytases are also classified based on their amino acid sequences, catalytic mechanisms, threedimensional conformation and biochemical properties ( $\beta$-propeller phytase [BPP], histidine acid phosphatases [HAP], purple acid phosphatases [PAP], or cysteine phosphatases [CP]) as well as optimum $\mathrm{pH}$ condition (alkaline or acid phytases) (Kumar et al. 2016). Acidic phytases have a $\mathrm{pH}$ optimum ranging from 3.0 to 5.5 while alkaline phytases from 7.0 to 8.0 (Yin et al., 2007; Vijayaraghavan et al., 2013). Like other proteins, most phytases are sensitive to high temperature and its optimum temperature is ranging from 50 to $60{ }^{\circ} \mathrm{C}$ (Igbasan et al., 2000). The variations of optimum condition for phytase activity and stability provide a wide choice of an enzyme to fit its application.

In plants, phytases are commonly found in oilseeds and nuts, legumes and in cereal pollen grains (Konietzny, 2002). Specifically, during seed germination, phytase activity increases to promote fast plant growth (Greiner, 2007). Phytases can also be found in plant roots, but with lower hydrolysis activity (Richardson et al., 2001). Many soil microorganisms, especially rhizosphere microorganisms species produce phytase as one of the mechanisms to increase phosphorus availability for plant growth, hence are used in biofertilizer. Some isolated phytate-degrading microorganisms are Pseudomonas sp. (Richardson et al., 2001, Jorquera et al., 2008, Singh et al., 2014, Sasirekha et al.,2012), Azotobacter, Rhizobium (AbdAlla, 1994, Singh et al., 2014), Azospirillum, Burkholderia (Unno et al., 2005, Singh et al., 2014), Enterobacter (Yoon et al., 1996, Cao et al., 2007, Jorquera et al., 2008), Pantoea (Jorquera et al., 2008), Serratia (Cao et al., 2007), Bacillus sp. (Joseph and Raj, 2007), and some other fungi. Production of phytases from various microorganisms has been demonstrated in different studies and this has been reviewed previously (Kumar et al. 2016). Characterization studies revealed phytases from soil micromycetes, yeast, Bacillus sp. and Enterobacter sp. exhibit high specific activity and show a broad range of optimum $\mathrm{pH}(\mathrm{pH} 3.5$ to 7.5$)$ and temperature $\left(37^{\circ} \mathrm{C}-\right.$ $\left.70^{\circ} \mathrm{C}\right)$.

In animal, there is evidence of phytase activity in stomach and intestine of pigs and broiler (Humer et al.
2014). Low stomach mucosal phytase activity has been discovered from pigs ( $\mathrm{Hu}$ et al. 1996) and broiler (Tamim et al., 2004). When fed low phosphorus diet, broilers have the adaptive ability by increasing intestinal phytase and phosphatase activity (McCuaig et al., 1972). Other than that, phytase are produced by gut microflora of the animal (Humer et al., 2014).

\section{Phytase in Animal Feed}

The animal feed industry holds a great importance to ensure quality and continuous food supply for the everincreasing world population. It plays a significant role in the food chain as it directly influences the quality of products like meat, milk, fish and eggs that people consume. The dependence on farm animals for human nutrition is huge around the globe, hence the animal feed should be highly nutritious and able to be absorbed by the animal effectively to produce animal's source foods with wholesome nutrition.

The major raw material for animal feed production are cereals and legumes-based ingredients such as soybean, corn, wheat and rapeseed meal. These plantbased protein meals contain 1-5\% of phytic acid (PA; myo-inositol [MI] hexaphosphoric acid), which is an anti-nutritional factor (Nissar et al., 2017). Phytic acid is the major phosphate storage compound in seeds and it represents $50-80 \%$ of total phosphate in plant seeds (Dersjant-Li et al., 2015). This anti-nutrient factor interferes with the absorption of several minerals, namely zinc, iron, calcium, magnesium, manganese, copper, and it reduces the digestibility of protein as well (Nissar et al., 2017). Phytate can be eliminated by the enzyme phytase through hydrolysis into inositol, phosphate and other divalent metals such as calcium, iron and zinc (Lei and Porres, 2003). Phytase is the enzyme highly used in animal feed compared to other enzymes such as xylanase, cellulase, amylase, protease and lipases, because phytase, unlike other enzymes is linked to absorption of more than one nutrient or mineral as mentioned previously.

The first commercial phytase products were introduced into feed market in 1991 in which the swine, poultry, and aquaculture feeds benefit from the application of phytase as a feed additive (Greiner and 
Konietzny, 2006). Moreover, phytase has a high marketing value which is estimated to surpass 300 million US dollars and continues to increase by $10 \%$ annually (Chen et al., 2015). Phytase enzymes work in multiple ways in an animal feed which renders benefit not only to the animal but also the environment and the feed manufacturers. For the animal nutrition, phytase aids in phosphate liberation from phytate which represents around $60-90 \%$ of total phosphate which otherwise would be wasted and pollutes the environment through the animal's excretion (Nissar et al., 2017).

Phosphorus is a key element in the animal cell biochemical reactions and bone mineralization. Phytase supplementation has been proven effective in bone mineralization and growth performance in broiler diets (Scholey et al., 2018). An improvement in phosphorus utilization also means that there is a reduction of phosphate waste excreted by the animal which is beneficial to the environment. Haefner et al. (2005) quoted that phosphorus excretion could be reduced to $50 \%$ with phytase application which is an important contribution towards environmental protection. In another study by Sugiura et al. (2001), phytase supplementation to rainbow trout diet has shown to increase nutrient digestibility and excretion of phosphorus was reduced to an extent of $95-98 \%$ compared with phosphorus excretion by fish consuming feeds without phytase thus reducing the occurrence of eutrophication. The feed manufacturers in another hand benefits from phytase enzyme because the addition of adequate amount of phytase reduces the dependency on phosphorus supplement which also reduces the feed production cost as well. Laboratory and field experiments have shown that $1 \mathrm{~g}$ of inorganic phosphorus supplementation can be replaced by 500 1000 units of phytase and reduce total phosphorus excretion by $30-50 \%$ (Yao et al., 2012). In a nutshell, the ability of phytase to augment the efficiency of animal feed in those three areas makes phytase a necessity rather than a choice for feed manufacturers.

\section{Phytases in poultry farming-functionality}

The poultry industry is one of the fastest and largest rising agro-based industries in the world. Broiler production is increasing every year due to higher demand by local consumers and export markets. It is projected that the growth in both production and consumption of poultry meat in developing countries will remain at the rate of $3.6 \%$ and $3.5 \%$ y-o-y respectively, till 2030 due to economic firmness, changing lifestyle and diet patterns (Global Poultry Feed Market, 2017). Malaysia is among the highest poultry meat per capita consumption in the world with consumption of 1.8 million chickens and 2.8 million chicken eggs daily (Market Research Report, 2017).

Poultry diets are mainly composed of seed-based components and contain the great amount of phosphorus in the phytic acid form. Phosphorus is a crucial mineral in the growth and development of poultry. It is, therefore, necessary to supplement poultry with the adequate amount of phosphorus. However, this phytic acid often forms the complex with other cations such as calcium and proteins which hinder the efficiency of absorption. Defiance in phosphorus, therefore, hinder poultry growth which can further leads to birds losing appetites, becoming weak and die (Haque et al., 2012). Therefore, phytase, an exogenous enzyme supplement is added to commercial poultry diets to overcome this issue.

Previous researchers reported that supplementation of phytases improves the performance of phosphate, calcium, magnesium, and zinc used (Viveros et al., 2002). Poultry fed phytase had higher digestibility for Val, Ile, nonessential amino acid and total amino acid (Namkung and Leeson, 1999; Ravindan et al., 1999). Transgenic corn derived phytase (TCDP) improve laying performance and ileal $\mathrm{P}$ utilization in laying hens (Gao et al., 2013).

Phytase present in the feed ingredients themselves has been shown to increase daily feed consumption which proportionally increases body weight gain as well as the growth-rate of poultry (Zhamuer, 2013; Bradbury et al.; 2017, Moss et al, 2017). Study conducted by Moss et al. (2017) shows that protease supplementation alone increase weight gains of poultry, but in combination with phytase decrease weight gain. In addition to that, the pre and post pallet whole grain addition to non-supplemented diet significantly 
improved apparent metabolizable energy (Moss et al 2017; Ravindran et al., 2000). Previous researchers also reported the efficacy of phytase on bone mineralization in poultry (Lalpanmawia et al.; 2014; Bradbury et al., 2017; Scholey et al., 2018). The benefit of phytase supplementation was greater in younger than older chicken (Li et al., 2018).

Interestingly, phytase has a great impact not only to the poultry itself but also to their lying performance It was reported that phytase is able to improve both quantity and quality of eggs which is the laying performance, egg mass and eggshell quality (Liu et al., 2007; Gao et al., 2013). Supplementation of microbial phytase to normal corn soybean diet can reduce Tricalcium Phosphate (TCP) level in the diet without affecting egg production, egg quality and ileal $\mathrm{p}$ utilization (Um and Paik, 1999). In addition to all the benefits mentioned, phytase was also found to be able to improve immunity measures in poultry (Ghosh et al., 2016). Combination of carbohydrates with phytase and acidifier decrease $E$. coli count and increase villus length in broiler chicken (Roofchaei et al., 2017). It was also reported that phytase improve immunity in broiler chicken to against New Castle Virus disease (Ghosh et al., 2016). Table 2 shows the summary of phytase functionality in poultry.

Table 2. Summary of phytase functionality in poultry

\begin{tabular}{|c|c|c|}
\hline No. & Functionality & Reference \\
\hline 1 & $\begin{array}{l}\text { Enhance broiler body weight gain and } \\
\text { performance }\end{array}$ & $\begin{array}{l}\text { Scholey et al., 2018; Broch et al., } 2018 \\
\text { Hamdi et al., 2018; Bradbury et al.,2017 } \\
\text { Moss et al, 2017; Morgan et al, } 2016 \\
\text { Chen et al., 2013; Sa et al., 2013; Dilger et al., 2004; Viveros et } \\
\text { al., 2002; Zyla, } 2001\end{array}$ \\
\hline 2 & Improve egg production & $\begin{array}{l}\text { Gao et al., 2013; Cabuk et al., 2004;Jalal and Scheideler, } \\
\text { 2001;Um and Paik, 1999; }\end{array}$ \\
\hline 3 & Enhance egg quality & $\begin{array}{l}\text { Gao et al., 2013; Cabuk et al., } 2004 \\
\text { Um and Paik, } 1999\end{array}$ \\
\hline 4 & Bone mineralization & $\begin{array}{l}\text { Scholey et al., 2018; Hamdi et al., 2018; Li et al., 2018; } \\
\text { Bradbury et al. (2017); Vieira et al.,2017; Lee et al, 2017; Gao } \\
\text { et al., 2013; Sa et al., 2013; Dilger et al., 2004; Zyla, } 2001\end{array}$ \\
\hline 5 & $\begin{array}{l}\text { Improve illeal digestibility performance of } \\
\text { Phosphorous, Calcium, Magnesium, Zinc or } \\
\text { Sodium in broiler chicken diets }\end{array}$ & $\begin{array}{l}\text { Moss et al., 2018; Kim et al., 2017; Viveros et al., 2002; Zyla, } \\
\text { 2001; Um and Paik, 1999; Hamdi et al., 2018; Gao et al., } 2013\end{array}$ \\
\hline 6 & Reduce liver weight & Viveros et al., 2002 \\
\hline 7 & $\begin{array}{l}\text { Improve digestibility of protein and amino acid } \\
\text { (Val, Ile, nonessential amino acid and total amino } \\
\text { acid) }\end{array}$ & $\begin{array}{l}\text { Moss et al., 2018; Sa et al., 2013; Zyla, 2001; Namkung and } \\
\text { Leeson, } 1999 \text { Ravindran et al., } 1999\end{array}$ \\
\hline 8 & Enhance Apparent Metaboliza Energy (AME) & $\begin{array}{l}\text { Moss et al, 2017; Ravindran et al., 2000; Namkung and Leeson, } \\
\text { 1999; }\end{array}$ \\
\hline 9 & Improve immunity against New Castle virus & Ghosh et al., 2016 \\
\hline 10 & Decrease E.coli count and enhanced villus length & Roofchaei et al., 2017 \\
\hline 11 & $\begin{array}{l}\text { Improved feed conversion ratio }(\mathrm{FCR}) \text { or feed } \\
\text { intake }\end{array}$ & $\begin{array}{l}\text { Bradbury et al.,2017; Moss et al, 2017;Lee et al, } \\
\text { 2017; Roofchaei et al., 2017; Sa et al., 2013 }\end{array}$ \\
\hline
\end{tabular}




\section{Conclusion and future perspectives}

This review showed clearly the positive effect of phytase supplementation that increase the growth performance, nutrients digestibility, optimized feed cost, improve sustainability of poultry production and reduce environmental pollution. Fundamental knowledge with respect to phytate and phytase is required in many aspects in order to produce an integrated form of understanding the correlation between phytase intake as poultry feed and minimizing removal in their manure. Investigation on genetically modified grains with reduced phytic acid content is another alternative that has potential in minimizing phosphorus lost.

\section{Acknowledgement}

Authors would like to acknowledge the support of MOHE and UTM-RMC through HICOE grant no. R.J130000.7846.4J262.

\section{References}

Abd-Alla, M.H. (1994). Use of organic phosphorus by Rhizobium leguminosarum biovarviceae phosphatases. Biol Fertil Soils, 18, 216-218. doi: 10.1007/BF00647669

Acamovic, T. (2001). Commercial application of enzyme technology for poultry production, World Poult Sci J, 57, 225-242. doi: 10.1079/WPS20010016

American Feed Industry Association (2018). AFIA Feed Industry Statistics. Arlington, VA, EEUU.

Ariff, R. M., Fitrianto, A., Manap, M. Y. A., Ideris, A., Kassim, A., Suhairin, A., Hussin, A. S. M. (2013). Cultivation conditions for phytase production from Recombinant Escherichia coli DH5a. Microbiol Insights, 6, MBI-S10402. doi: 10.4137/MBI.S10402

Bedford, M.R., Schulze, H. (1998). Exogenous enzymes for pigs and poultry, Nutr Res Rev, 11, 91-114. doi: 10.1079/NRR19980007

Beshay, U., El Enshasy, H., Ismail, I.M.K, Moawad, H., Abdel Ghany, S. (2003). Glucanase production from genetically modified recombinant Escherichia coli: Effect of Growth Substrates and Development of a Culture Medium in Shake Flasks and Stirred Tank Bioreactor. Process Biochem, 39, 307-313.

Beshay, U., El Enshasy, H., Ismail, I.M.K., Moawad, H., Abd El-Ghany, S. (2011). Beta-Glucanase productivity improvement via cell immobilization of recombinant Escherichia coli cells in different matrices. Polish $J$ Microbiol, 60, 133-138.
Bradbury, E.J., Wilkinson, S.J., Cronin, G.M., Thomson, P., Walk, C.L., Cowieson, A.J. (2017). Evaluation of the effect of a highly soluble calcium source in broiler diets supplemented with phytase on performance, nutrient digestibility, foot ash, mobility and leg weakness. Anim Prod Sci, 57(10), 2016-2026. doi: 10.1071/AN16142

Broch, J., Nunes, R. V., Eyng, C., Pesti, G. M., de Souza, C., Sangalli, G. G., Teixeira, L. (2018). Effect of dietary phytase superdosing on broiler performance. Anim Feed Sci Technol doi: 10.1016/j.anifeedsci.2018.06.001

Cabuk, M., Bozkurt, M., Kyrkpynar, F., Ozkul, H. (2004). Effect of phytase supplementation of diets with different levels of phosphorus on performance and egg quality of laying hens in hot climatic conditions. $S$ Afr $J$ Anim Sci, 34(1), 13-17.doi: 10.4314/sajas.v34i1.3804

Cao, L., Wang, W., Yang, C., Yang, Y., Diana, J., Yakupitiyage, A., Luo, Z., Li, D. (2007). Application of microbial phytase infish feed. Enzyme Microb Technol, 40, 497-507.doi: 10.1016/j.enzmictec.2007.01.007

Charoenrat, T., Antimanon, S., Kocharin, K., Tanapongpipat, S., Roongsawang, N. (2016). High cell density process for constitutive production of a recombinant phytase in thermotolerant methylotrophic yeast Ogataea thermomethanolica using table sugar as carbon source. Appl Biochem Biotechnol, 180(8), 16181634. doi: $10.1007 / \mathrm{s} 12010-016-2191-8$

Chen, C.C., Cheng, K.J., Ko, T.P., Guo, R.T. (2015). Current progresses in phytase research: three-dimensional structure and protein engineering. Chem Bio Eng Reviews, 2(2), 76-86. doi: 10.1002/cben.201400026

Chen, Y.P., Duan, W.G., Wang, L. L., Zhang, S. L., Zhou, Y.M. (2013). Effects of thermostable phytase supplementation on the growth performance and nutrient digestibility of broilers. Int J Poult Sci 12(8), 441. doi: 10.3923/ijps.2013.441.444

Danicke, S., Jeroch, H., Bottcher, W., Bedford, M.R., Ortwin, S. (1999). Effects of dietary fat type, pentosan level and xylanases on digestibility of fatty acids, liver lipids and vitamin E in broilers, Fettl Lipid, 101(3), 90$100 . \quad$ doi: 10.1002/(SICI)15214133(199903)101:3<90::AID-LIPI90>3.0.CO;2-Q

Dersjant-Li, Y., Awati, A., Schulze, H., Partridge, G. (2015). Phytase in non-ruminant animal nutrition: a critical review on phytase activities in the gastrointestinal tract and influencing factors. J Sci Food Agric, 95(5), 878-896. doi: 10.1002/jsfa.6998

Dilger, R.N., Onyango, E.M., Sands, J.S., Adeola, O. (2004). Evaluation of microbial phytase in broiler diets. Poult Sci, 83(6), 962-970. doi: 10.1093/ps/83.6.962

El Enshasy, H.A., Abdel Fattah, Y., Othman, N.Z. (2013). Amylases. In: Bioprocessing technologies in integrated biorefinery from production of biofuels, biochemicals, and biopolymers from biomass. Yang S-T, El Enshasy HA, Thongchul N (edts), First ed. John Wiley \& Sons, USA 111-130.

El Enshasy, H.A., Othman, N.Z., Elsayed, E.A., Sarmidi, M.R., Wadaan, M.A., Aziz, R. (2016a). Functional enzymes for animal feed applications. In: The hand book 
of microbial bioresources. Gupta VK, Sharma GD, Touhy MG, Gaur R (edts), CABI Oxfordshire, UK. 296-312.

El Enshasy, H.A., Kandiyil, S.K., Malek, R., Othman, N.Z. (2016b). Xylanases: Sources, types and their applications. In: microbial enzymes in bioconversions of biomass. Gupta VK (ed). Springer International Publishing, Switzerland. 151-213.

Elsayed, E.A., Omar, H.G., Abdel Galil, S., El Enshasy, H.A. (2016). Optimization of fed-batch cultivation for extracellular $\alpha$-amylase production by Bacillus amyloliquefaciens in submerged culture. J Sci Ind Res, 75, 480-486.

Gao, C.Q., Ji, C., Zhang, J.Y., Zhao, L.H., Ma, Q.G. (2013). Effect of a novel plant phytase on performance, egg quality, apparent ileal nutrient digestibility and bone mineralization of laying hens fed corn-soybean diets. Anim Feed Sci Technol, 186,1-2, 101-105. doi: 10.1016/j.anifeedsci.2013.09.011

Ghosh, A., Mandal, G.P., Roy, A., Patra, A.K. (2016). Effects of supplementation of manganese with or without phytase on growth performance, carcass traits, muscle and tibia composition, and immunity in broiler chickens. Livest $\quad$ Sci, 191, 80-85. doi: 10.1016/j.livsci.2016.07.014

Global Poultry Feed Market Report (2017). Analysis \& Forecasts 2013-2021 - Emphasis on industrialization of livestock industry in Asia and South America

Greiner, R. (2007). Phytate-degrading enzymes: Regulation of synthesis in microorganisms and plants In: Turner, B.L. and Mullaney, E.J., Eds., Inositol Phosphates: Linking agriculture and the environment, CABI, Wallingford, UK, 78-96. doi: 10.1079/9781845931520.0078

Greiner, R., Konietzny, U. (2006). Phytase for food application. Food Technol Biotechnol, 44(2). 125-140.

Haefner, S., Knietsch, A., Scholten, E., Braun, J., Lohscheidt, M., Zelder, O. (2005). Biotechnological production and applications of phytases. Appl Microbiol Biotechnol, 68(5), 588-597. doi: 10.1007/s00253-0050005-y

Hamdi, M., Perez, J. F., Létourneau-Montminy, M. P., Franco-Rosselló, R., Aligue, R., Solà-Oriol, D. (2018). The effects of microbial phytases and dietary calcium and phosphorus levels on the productive performance and bone mineralization of broilers. Anim Feed Sci Technol doi: 10.1016/j.anifeedsci.2018.07.005

Haque, N., Hossain, A., Kumar, M., Kumar, V., Tyagi, A.K. (2012). Phytase: their biochemistry, physiology and application in poultry. Int $J$ Livest Res, 2(2), 30-41. doi: 10.5455/ijlr.20120407060451

Hu, H.L., Wise, A., Henderson, C. (1996). Hydrolysis of phytate and inositol tri-, tetra-, and penta-phosphates by the intestinal mucosa of the pig. Nutr Res, 16, 781-787. doi: 10.1016/0271-5317(96)00070-X

Humer, E., Schwarz, C., Schedle, K. (2014). Phytate in pig and poultry nutrition. $J$ Anim Physiol Anim Nutr 99(4),605-625, doi:10.1111/jpn.12258
Igbasan, F.A., Männer, K., Miksch, G., Borriss, R., Farouk, A., Simon, O. (2000). Comparative studies on the in vitro properties of phytases from various microbial origins. Arch Anim Nutr, 53(4), 353-373. doi: 10.1080/17450390009381958

Jalal, M., Scheideler, S.E. (2001). Effect of supplementation of two different sources of phytase on egg production parameters in laying hens and nutrient digestibility. Poultry Sci, 80(10), 14631471.doi: $10.1093 / \mathrm{ps} / 80.10 .1463$

Jorquera, M., Martinez, O., Maruyama, F., Marschner, P., Mora de la Luz, M. (2008). Current and future biotechnological applications of bacterial phytases and phytase-producing bacteria. Microbes Environ, 23, 182191. doi: $10.1264 /$ jsme2.23.182

Joseph, I., Raj, R.P. (2007). Isolation and characterization of phytase producing Bacillus strains from mangrove ecosystem. J Marine Biol Ass India, 49,177-182.

Kandiyil, S., Abdul Malek, R., Aziz, R., El Enshasy, H.A. (2018). Development of an industrial feasible medium for enhanced production of extremely thermophilic recombinant Endo-1,4- $\beta$ Xylanase by Escherichia coli. $J$ Sci Ind Res, 77, 41-49.

Kim, J.H., Han, G.P., Shin, J.E., Kil, D.Y. (2017). Effect of dietary calcium concentrations in phytase-containing diets on growth performance, bone mineralization, litter quality, and footpad dermatitis score in broiler chickens. Anim Feed Sci Technol, 229, 13-18. doi: 10.1016/j.anifeedsci.2017.04.008

Konietzny, U.G. (2002). Molecular and Catalytic Properties of Phytate-Degrading Enzymes (Phytases). Int J Food Sci Technol, 37, 791-812. doi: 10.1046/j.13652621.2002.00617.x

Kumar, A., Chanderman, A., Makolomakwa, M., Perumal, K, Singh, S. (2016). Microbial production of phytases for combating environmental phosphate pollution and other diverse applications. Crit Rev Environ Sci Technol 46(6), 556-591 doi:10.1080/10643389.2015.1131562

Lan, J. C. W., Chang, C. K., Wu, H. S. (2014). Efficient production of mutant phytase (phyA-7) derived from Selenomonas ruminantium using recombinant Escherichia coli in pilot scale. J Biosci Bioeng. 118(3), 305-310. doi: 10.1016/j.jbiosc.2014.02.024.

Lalpanmawia, H., Elangovan, A.V., Sridhar, M., Shet, D., Ajith, S., Pal, D.T. (2014). Efficacy of phytase on growth performance, nutrient utilization and bone mineralization in broiler chicken. Anim Feed Sci Technol, 192, 81-89. doi: 10.1016/j.anifeedsci.2014.03.004

Lee, S.A., Nagalakshmi, D., Raju, M.V., Rao, S.V.R., Bedford, M.R. (2017). Effect of phytase superdosing, myo-inositol and available phosphorus concentrations on performance and bone mineralisation in broilers. Anim Nutr, 3(3), 247-251. doi: 10.1016/j.aninu.2017.07.002

Lei, X.G., Porres, J.M. (2003). Phytase enzymology, applications, and biotechnology. Biotechnol Lett, 25(21), 1787-1794. doi: 10.1038/nbt0793-811. 
Li, W., Angel, R., Kim, S. W., Jiménez-Moreno, E., Proszkowiec-Weglarz, M., Plumstead, P.W. (2018). Impacts of age and calcium on Phytase efficacy in broiler chickens. Anim Feed Sci Technol, 238, 9-17. doi: 10.1016/j.anifeedsci.2018.01.021

Liu, N., Liu, G. H., Li, F.D., Sands, J.S., Zhang, S., Zheng, A.J., Ru, Y.J. (2007). Efficacy of phytases on egg production and nutrient digestibility in layers fed reduced phosphorus diets. Poultry Sci, 86(11), 23372342.doi: 10.3382/ps.2007-00079

Market Research Report (2017). Poultry Sector in South East Asia, Orissa International Pte. Ltd.

McCuaig, L., W. Davies, M.I., Motzok, I. (1972). Regulation of intestinal alkaline phosphatase and phytase of chicks: effects of dietary magnesium, calcium, phosphorus and thyroactive casein. Poult Sci, 51, 526530. doi:10.3382/ps.0510526

Mirzaei, M., Saffar, B., Shareghi, B. (2016). Cloning, codon optimization, and expression of Yersinia intermedia phytase gene in E. coli. Iran $J$ Biotechnol, 14(2), 63. doi: 10.15171/ijb.1412

Morgan, N.K., Walk, C.L., Bedford, M.R., Scholey, D.V., Burton, E.J. (2016). Effect of feeding broilers diets differing in susceptible phytate content. Anim Nutr, 2(1), 33-39. doi:10.1016/j.aninu.2016.01.002

Moss, A.F., Chrystal, P.V., Dersjant-Li, Y., Selle, P.H., Liu, S.Y. (2018). Responses in digestibilities of macrominerals, trace minerals and amino acids generated by exogenous phytase and xylanase in canola meal diets offered to broiler chickens. Anim Feed Sci Technol, 240, 22-30. doi: 10.1016/j.anifeedsci.2018.03.011

Moss, A.F., Chrystal, P.V., Truong, H.H., Liu, S.Y., Selle, P H. (2017). Effects of phytase inclusions in diets containing ground wheat or $12.5 \%$ whole wheat (pre-and post-pellet) and phytase and protease additions, individually and in combination, to diets containing $12.5 \%$ pre-pellet whole wheat on the performance of broiler chickens. Anim Feed Sci Technol, 234, 139-150. Doi: 10.1016/j.anifeedsci.2017.09.007

Namkung, H., Leeson, S. (1999). Effect of phytase enzyme on dietary nitrogen-corrected apparent metabolizable energy and the ileal digestibility of nitrogen and amino acids in broiler chicks. Poult Sci, 78(9), 1317-1319. doi: 10.1093/ps/78.9.1317

Nissar, J., Ahad, T., Naik, H.R., Hussain, S.Z. (2017). A review phytic acid: As antinutrient or nutraceutical. $J$ Pharmacogn Phytochem, 6(6), 1554-1560.

Pariza, M.W., Cook, M. (2010). Determining the safety of enzymes used in animal feed, Regul Toxicol Pharmacol, 56, 332-342. doi: 10.1016/j.yrtph.2009.10.005

Pakbaten, B., Heravi, R. M., Kermanshahi, H., Sekhavati, M. H., Javadmanesh, A., Ziarat, M.M. (2018). Production of phytase enzyme by a bioengineered probiotic for degrading of phytate phosphorus in the digestive tract of poultry. Probiotics Antimicrob Proteins, 1-8. doi: 10.1007/s12602-018-9423-x

Pen, J., Verwoerd, T.C., van Paridon, P. A., Beudeker, R.F., van den Elzen, P., Geerse, K., \& Hoekema, A.
(1993). Phytase-containing transgenic seeds as a novel feed additive for improved phosphorus utilization. Nat. Biotechnol., 11(7), 811.

Ravindran, V., Cabahug, S., Ravindran, G., Bryden, W.L. (1999). Influence of microbial phytase on apparent ileal amino acid digestibility of feedstuffs for broilers. Poult Sci,78(5), 699-706. doi: 10.1093/ps/78.5.699

Ravindran, V., Cabahug, S., Ravindran, G., Selle, P.H., Bryden, W.L. (2000). Response of broiler chickens to microbial phytase supplementation as influenced by dietary phytic acid and non-phytate phosphorous levels. II. Effects on apparent metabolisable energy, nutrient digestibility and nutrient retention. Br Poult Sci,41(2), 193-200. doi: 10.1080/00071660050022263

Reddy, N.R., Sathe, S.K., Salunkhe, D.K. (1982). Phytates in legumes and cereals. In Advances in food research (Vol. 28, pp. 1-92). Academic Press. doi: 10.1016/S0065-2628(08)60110-X

Richardson, A.E., Hayes, J.E. (2000). Acid Phosphomonoesterase and Phytase Activities of Wheat (Triticum aestivum L.) Roots and utilization of organic phosphorus substrates by seedlings grown in sterile culture. Plant Cell Environ, 23, 397-405. doi:10.1046/j.1365-3040.2000.00557.x

Richardson, A.E., Hadobas, P.A., Hayes, J.E. (2001). Extracellular Secretion of Aspergillus Phytase from Arabidopsis Roots Enables Plants to Obtain Phosphorus from Phytate. Plant J, 25, 641-649. doi: 10.1046/j.1365313x.2001.00998.x

Roofchaei, A., Rezaeipour, V., Vatandour, S., Zaefarian, F. (2017). Influence of dietary carbohydrases, individually or in combination with phytase or an acidifier, on performance, gut morphology and microbial population in broiler chickens fed a wheat-based diet. Anim Nutr. doi: 10.1016/j.aninu.2017.12.001

Roy, M. P., Mazumdar, D., Dutta, S., Saha, S. P., Ghosh, S. (2016). Cloning and expression of phytase appA gene from Shigella sp. CD2 in Pichia pastoris and comparison of properties with recombinant enzyme expressed in $E$. coli. PloS one, 11(1), e0145745. Doi: 10.1371/journal.pone.0145745

Sa, K., Hr, C., Ys, B. (2013). The effect of phytase enzyme on the performance of broiler flock (A-Review). Poultry Sci, 1(2), 117-125.doi: 10.22069/PSJ.2013.1478

Sabir, F., Tayyab, M., Muneer, B., Hashmi, A. S., Awan, A. R., Rashid, N., Firyal, S. (2017). Characterization of recombinant thermostable phytase from thermotoga naphthophila: A step for the fulfilment of domestic requirement of phytase in Pakistan. Pak J Zool, 49(6). doi: 10.17582/journal.pjz/2017.49.6.1945.1951

Sasirekha, B., Bedashree, T., Champa, K. (2012). Optimization and partial purification of extracellular phytase from Pseudomonas aeruginosa p6. Euro J Exp Bio, 2,95-104.

Scholey, D.V., Morgan, N.K., Riemensperger, A., Hardy, R., Burton, E.J (2018). Effect of supplementation of phytase to diets low in inorganic phosphorus on growth 
performance and mineralization of broilers. Poult Sci, 97(7), 2435-2440. doi: 10.3382/ps/pey088

Selle, P.H., Ravindran, V. (2007). Microbial phytase in poultry nutrition. Anim. Feed Sci. Technol, 135,1-41. doi: 10.1016/j.anifeedsci.2006.06.010

Silversides, F. G., Hruby, M. (2009). Feed formulation using phytase in laying hen diets. J Appl Poult Res, 18(1), 15-22. doi: 10.3382/japr.2008-00035

Silversides, F.G., Bedford, M.R. (1999). Effect of pelleting temperature on the recovery and efficacy of a xylanase enzyme in wheat-based diets, Poult Sci, 78,1184-1190. doi:10.1093/ps/78.8.1184

hydrolysis in broiler chickens. Poult Scie, 83, 1358-1367 doi: $10.1093 / \mathrm{ps} / 83.8 .1358$

Tai, H. M., Yin, L. J., Chen, W. C., Jiang, S. T. (2013). Overexpression of Escherichia coli phytase in Pichia pastoris and its biochemical properties. J Agric Food Chem, 61(25), 6007-6015. doi: 10.1021/jf401853b

Um, J. S., Paik, I. K. (1999). Effects of microbial phytase supplementation on egg production, eggshell quality, and mineral retention of laying hens fed different levels of phosphorus. Poult Sci, 78(1), 75-79. doi: $10.1093 / \mathrm{ps} / 78.1 .75$

Unno, Y., Okubo, K., Wasaki, J., Shinano, T., Osaki, M. (2005). Plant growth promotion abilities and microscale bacterial dynamics in the rhizosphere of lupin analysed by phytate utilization ability. Environ Microbiol, 7, 396404. doi: 10.1111/j.1462-2920.2004.00701.x

Vieira, B.S., Silva, F.G., Oliveira, C.F.S., Correa, A.B., Junior, J.C., Correa, G.S.S. (2017). Does citric acid improve performance and bone mineralization of broilers when combined with phytase? A systematic review and meta-analysis. Anim Feed Sci Technol, 232, 21-30. doi: 10.1016/j.anifeedsci.2017.07.016

Vijayaraghavan, P., Primiya, R.R., Vincent, S.G.P. (2013). Thermostable alkaline phytase from Alcaligenes sp. in improving bioavailability of phosphorus in animal feed. In vitro analysis. ISRN Biotechnology, 1-6. doi; $10.5402 / 2013 / 394305$

Viveros, A., Brenes, A., Arija, I., Centeno, C. (2002). Effects of microbial phytase supplementation on mineral utilization and serum enzyme activities in broiler chicks fed different levels of phosphorus. Poult Sci, 81(8), 11721183. doi: $10.1093 / \mathrm{ps} / 81.8 .1172$

Yao, M. Z., Zhang, Y. H., Lu, W. L., Hu, M. Q., Wang, W., Liang, A. H. (2012). Phytases: crystal structures, protein engineering and potential biotechnological applications. J Appl Microbiol, 112(1), 1-14. doi; 10.1111/j.1365-2672.2011.05181.x

Yin, Q. Q., Zheng, Q.H., Kang, X.T. (2007). Biochemical characteristics of phytases from fungi and the transformed microorganism. Anim Feed Sci Technol, 132, 341-350. doi: 10.1016/j.anifeedsci.2006.03.016

Yoon, S.J., Min, H.K., Cho, K.K., Kim, J.W., Lee, S.C., Jung, Y.H. (1996). Isolation and Identification of phytase-producing bacterium, Enterobacter sp. 4, and enzymatic properties of phytase enzyme. Enzyme Microb
Singh, P., Kumar, V., Agrawal, S. (2014). Evaluation of phytase producing bacteria for their plant growth promoting activities. Int J Microbiol, 2014, Article ID: 426483. doi: 10.1155/2014/426483

Sugiura, S.H., Gabaudan, J., Dong, F. M., Hardy, R.W. (2001). Dietary microbial phytase supplementation and the utilization of phosphorus, trace minerals and protein by rainbow trout [Oncorhynchus mykiss (Walbaum)] fed soybean meal-based diets. Aquac Res, 32(7), 583-592. doi:10.1046/j.1365-2109.2001.00581.x

Tamim, N. M., Angel, R.; Christman, M. (2004). Influence of dietary calcium and phytase on phytate phosphorus Technol, 18, 449-454. doi: 10.1016/01410229(95)00131-X

Zhamuer, M. (2013). The effect of phytase supplementation on broiler and interaction between phytase and intermittent feeding and structural components (Master's thesis, Norwegian University of Life Sciences, Ås)

Zyla, K. (2001). Phytase applications in poultry feeding: Selected issues. J Anim Feed Sci, 10(2), 247-258. doi: $10.22358 /$ jafs/67981/2001 